JEKPEND Jurnal Ekonomi dan Pendidikan

Volume 1 Nomor 1 Januari 2018. Hal 97-105

p-ISSN: 2614-2139; e-ISSN: 2614-1973,

Homepage: http://ojs.unm.ac.id/JEKPEND

\title{
EVALUASI PENYELENGGARAAN UJIAN AKHIR SEMESTER MAHASISWA PROGRAM NON PENDIDIKAN DASAR DI UPBJJ-UT MAKASSAR
}

\author{
Kadariah \\ Program Studi Manajemen Pendidikan Universitas Terbuka, Makassar \\ Email: kadariah@ecampus.ut.ac.id
}

\begin{abstract}
The study aims to describe the successful implementation of UAS Non Pendas program in UPBJJ-UT Makassar for the examination period 2017.1. The population in this study were students of UAS, PJTU, PJLU, PK, PR and Administrative Staff in UPBJJ-UT Makassar consisting of 191 respondents with 92 question items. The research data consist of evaluation result of successful implementation of UAS Non-Pendas program at UPBJJ-UT Makassar for the examination period 2017.1. Data analysis using descriptive statistics. The results showed that: 1). Responsible Examination Place (PJTU) and Responsible Exam Location (PJLU) performs the task well; 2). The traveling supervisor stated that the implementation of UAS Non Pendas program in UPBJJ-UT is effective and efficient; and 3). Perceptions of Administrative Staff on the implementation of UAS Non-Pendas program at UPBJJ-UT Makassar for the examination period 2017.1 is still less effective.
\end{abstract}

Keywords: Successful Implementation of UAS

\begin{abstract}
Abstrak. Penelitian bertujuan untuk mendeskripsikan keberhasilan pelaksanaan UAS program Non Pendas di UPBJJ-UT Makassar untuk masa ujian 2017.1. Populasi dalam penelitian ini adalah mahasiswa peserta UAS, PJTU, PJLU, PK, PR dan Tenaga Administrasi di wilayah UPBJJ-UT Makassar yang terdiri atas 191 orang responden dengan 92 item pertanyaan. Data penelitian terdiri dari hasil evaluasi keberhasilan pelaksanaan UAS program Non Pendas di UPBJJ-UT Makassar untuk masa ujian 2017.1. Analisis data menggunakan statistik deskriptif. Hasil penelitian menunjukkan bahwa: 1). Penanggung Jawab Tempat Ujian (PJTU) dan Penanggung Jawab Lokasi Ujian (PJLU) melaksanakan tugas dengan baik; 2). Pengawas keliling menyatakan bahwa pelaksanaan UAS program Non Pendas di UPBJJ-UT berjalan efektif dan efisien; dan 3). Persepsi Tenaga Administrasi tentang pelaksanaan UAS program Non Pendas di UPBJJ-UT Makassar untuk masa ujian 2017.1 masih kurang efektif.
\end{abstract}

Kata Kunci: Keberhasilan Pelaksanaan UAS

\section{PENDAHULUAN}

Penyelenggaraan Ujian Akhir Semester (UAS) di Universitas Terbuka (UT) pada program Non Pendidikan Dasar (Non Pendas) tahun 2016 dilakukan oleh 39 Unit Program Belajar Jarak Jauh (UPBJJ) di 261 tempat ujian yang tersebar diseluruh Indonesia. Bahan ujiannya diproduksi secara terpusat di UT Pusat dan dikembangkan oleh para dosen senior perguruan tinggi negeri yang juga bertindak sebagai penulis Buku Materi Pokok (BMP). Bahan UAS tersebut dikirimkan ke seluruh tempat ujian yang telah ditetapkan oleh UT Pusat beberapa saat menjelang ujian berlangsung melalui sistem pengiriman pos khusus dalam hal ini PT. Pos Indonesia yang sudah bekerjasama dengan UT.

Ujian akhir semester bertujuan untuk menguji kemampuan mahasiswa dalam menguasai materi suatu mata kuliah. Soalsoal UAS dikembangkan di UT Pusat dalam bentuk tes objektif dan tes uraian. Pada saat pelaksanaan UAS mahasiswa menjawab soal ujian pada Lembar Jawaban Ujian (LJU) untuk mengerjakan tes objektif, dan pada 
Buku Jawaban Ujian (BJU) untuk mengerjakan tes uraian. Seluruh penyelenggaraan UAS di daerah yang sudah ditunjuk sebagai tempat ujian oleh UT Pusat diatur oleh UPBJJ setempat. Hasil UAS yang berbentuk tes objektif dinilai secara terpusat di UT Pusat dengan menggunakan komputer, sedangkan hasil UAS uraian dinilai oleh dosen yang berada pada rayon UPBJJ sentra yang telah ditentukan oleh UT Pusat. UPBJJ-UT Makassar merupakan salah satu UPBJJ sentra untuk wilayah Indonesia Timur yang meliputi 10 UPBJJ yaitu: Makassar, Majene, Manado, Gorontalo, Palu, Kendari, Ternate, Ambon, Jayapura, dan Sorong.

Untuk penilaian akhir dari hasil UAS mahasiswa akan dilakukan pemeriksaan LJU dengan melihat ada tidaknya keganjilan nilai yang dicapai oleh sekelompok mahasiswa di setiap ruang ujian. Keganjilan tersebut dapat disebabkan adanya kecurangan yang menimbulkan pola jawaban sama. Bahkan hasil ujian mahasiswa tidak dapat diproses karena adanya ketidaksamaan tanda tangan pada LJU/BJU dengan daftar hadir, serta adanya pelanggaran tata tertib ujian yang dilakukan oleh mahasiswa.

Pada masa ujian 2016.1 mahasiswa program Non Pendas yang mengalami kasus nilai sebanyak 3 dari $4517(0,07 \%)$ peserta UAS yang terdapat di 8 tempat ujian resmi di wilayah UPBJJ-UT Makassar. Sedangkan pada masa ujian 2016.2 mahasiswa yang mengalami kasus nilai sebanyak 3 dari 8871 $(0,03 \%)$ peserta UAS.yang terdapat pada 8 tempat ujian di wilayah UPBJJ-UT Makassar. Pelanggaran yang dilakukan oleh mahasiswa program Non Pendas untuk masa ujian tersebut ada 2 jenis yaitu: melakukan tanda tangan berbeda di LJU dengan daftar hadir, dan (Data sekunder: Pusjian, 2016). Kasus nilai yang dialami oleh mahasiswa program Non Pendas di UPBJJ-UT Makassar merupakan kesalahan yang sama pada dua semester secara berturut-turut.

Pengalaman peneliti dalam melaksanakan tugas sebagai Penanggung Jawab Tempat Ujian (PJTU) baik pada program Non Pendas maupun Pendas menemukan masih banyak mahasiswa peserta UAS yang tidak siap mengikuti ujian. Hal ini terlihat dari kurang percaya diri mahasiswa dalam mengerjakan soal-soal UAS sehingga melakukan kesalahan oleh mahasiswa tersebut menyebabkan nilainya keluar dengan nilai hukuman $(\mathrm{H})$.

Menurut Suparman (2005), pelanggaran yang dilakukan oleh mahasiswa pada saat ujian disebabkan oleh pengawas ruangan ujian mengalami kejenuhan karena seharian penuh mengawasi satu ruangan saja sehingga menyebabkan kurang tertibnya pengawasan dan suasana ujian kurang kondusif, cenderung kurang menaati aturan, dan bila terjadi pelanggaran pada peserta ujian tidak diberikan sangsi sesuai dengan tata tertib yang ada.

Sedangkan menurut Zaidin (2009), hasil pelaksanaan UAS 2009.2 di UPBJJ-UT Makassar dilaporkan bahwa belum berjalan secara maksimal karena kurangnya pemahaman para: Penanggung Jawab Tempat Ujian (PJTU), Penanggung Jawab Lokasi Ujian (PJLU), Pengawas Ruang (PR), dan Pengawas Keliling (PK) terhadap tugas yang diembannya. Lebih lanjut Zaidin (2009) menyatakan bahwa, penyimpangan prosedur dan tata tertib ujian disebabkan karena para PJTU belum maksimal dalam melakukan penyamaan persepsi terhadap PJLU, PR, dan PK di tempat ujian masingmasing.

Untuk mengetahui sejauh mana keberhasilan pelaksanaan UAS program Non Pendas di UPBJJ-UT Makassar untuk masa ujian 2017.1 perlu dilakukan evaluasi terhadap persiapan dan pelaksanaannya. Sehubungan dengan uraian pada latar belakang ini perlu dilakukan penelitian dengan judul "Evaluasi Penyelenggaraan Ujian Akhir Semester Mahasiswa Program Non Pendidikan Dasar di UPBJJ-UT Makassar".

Berdasarkan uraian di atas, maka permasalahan dalam penelitian ini dapat dirumuskan sebagai berikut : "Permasalahan dalam penelitian ini adalah upaya untuk meningkatkan pelaksanaan UAS pada program Non Pendas di UPBJJ- 
UT Makassar. Masalah ini dapat dirumuskan "Bagaimana pelaksanaan ujian akhir semester (UAS) mahasiswa program Non Pendas pada masa ujian 2017.1 di UPBJJ-UT Makassar?”.

\section{METODE PENELITIAN}

Penelitian ini dilakukan bertujuan untuk mengungkap keberhasilan pelaksanaan UAS pada program Non Pendas di UPBJJ-UT Makassar. Secara khusus, penelitian ini bertujuan untuk mengevaluasi pelaksanaan UAS mahasiswa program Non Pendas masa ujian 2017.1 di UPBJJ-UT Makassar.

Penelitian ini dilakukan di wilayah UPBJJ-UT Makassar yang terdiri dari Kabupaten/Kota Makassar, Palopo, Sinjai. Penelitian ini dilakukan dengan beberapa tahapan. Pertama pra survei untuk menganalisis persiapan pelaksanaan UAS mulai dari administrasi sampai dengan persiapan lokasi ujian yang akan digunakan. Hal ini dilakukan agar dapat bekerja sama dengan penyelenggara daerah (PJLU, PK, PR dan Tenaga Adaministrasi) dan persiapan pembuatan instrumennya. Tahap kedua, pengumpulan data yang dilakukan dengan memberikan kuesioner kepada pelaksana kegiatan, yaitu panitia tingkat kabupaten, PJLU, PK, PR,Tenaga Administrasi dan Mahasiswa.Tahapan ini dilakukan untuk memperoleh data tentang kesiapan sarana, prasarana, dan administrasi penyelenggaraan UAS. Tahap ketiga, pengumpulan data saat pelaksanaan UAS berlangsung.

Kegiatan ini dimaksudkan untuk memperoleh data tentang pelaksanaan UAS itu sendiri. Adapun yang menjadi objek penelitian adalah proses pelaksanaan UAS program Non Pendas di UPBJJ-UT Makassar masa ujian 2017.

Adapun instrumen yang digunakan adalah kuesioner, lembar observasi, dan lembar wawancara. Pendekatan yang digunakan dalam pelaksaan evaluasi adalah pendekatan yang berorientasi pada tujuan atau Goal Oriented Approach. Pendekatan ini menggunakan tujuan program sebagai kriteria untuk menentukan keberhasilannya.
Sumber data dalam penelitian ini adalah mereka yang berhubungan langsung dengan pelaksanaan (UAS) antara lain: PJTU, PJLU, PK, PR, Tenaga Administrasi dan mahasiswa peserta ujian yang terlibat dalam pelaksanaan UAS di UPBJJ-UT Makassar.

Populasi dalam penelitian ini adalah mahasiswa peserta UAS, PJTU, PJLU, PK, PR dan Tenaga Administrasi di wilayah UPBJJ-UT Makassar yang terdiri atas 191 orang responden dengan 92 item pertanyaan - Adapun yang menjadi objek penelitian adalah proses pelaksanaan UAS program Non Pendas di UPBJJ-UT Makassar masa ujian 2017.1. Penarikan sampel dilakukan dengan metode Cluster Proportional Random Sampling. Pengelompokan sampel dilakukan berdasarkan kondisi geografis UPBJJ-UT Makassar yang berada pada daerah dua dimensi yaitu darat, dan pegunungan.Untuk tempat UAS pada dua daerah tersebut adalah Kota Makassar, Kota Palopo dan Kab.Sinjai. Jumlah sampel penelitian yang ditetapkan adalah $10 \%$ dari keseluruhan populasi pada ketiga daerah tersebut (Gay, 1987).

Teknik analisis data. Data yang terkumpul yang diperoleh dari sampel penelitian, akan diolah/dianalisis dengan menggunakan teknik analisis deskriptif, yaitu prosentase (\%), guna menjawab permasalahan yang telah dirumuskan pada bab terdahulu. Sesuai yang dikemukakan oleh Sugiyono (2009:43) yaitu:

$$
\mathrm{P}=\frac{F}{N} \times 100 \%
$$

Keterangan :

$\mathrm{F}=$ frekuensi yang sedang dicari

persentasenya

$\mathrm{N}=$ Number of Cases (jumlah frekuensi/ banyaknya individu

$\mathrm{P}=$ Angka persentase

Selanjutnya setelah diperoleh hasil dari interprestasi dari persentase nilai akhir, maka ditarik kesimpulan sesuai yang dikemukakan oleh Sugiyono (2001:81) bahwa apabila persentase berada pada: 


$$
\begin{aligned}
& \text { 1. } 76 \%-100 \% \text { = kategori efektif dan } \\
& \text { efisien } \\
& \text { 2. }<76 \%=\text { kategori kurang } \\
& \text { efektif. }
\end{aligned}
$$

\section{HASIL DAN PEMBAHASAN}

Penyajian dan analisis data dimaksudkan untuk menjawab permasalahan-permasalahan yang diajukan. Data yang disajikan dalam bagian ini adalah data yang diperoleh melalui penyebaran kuesioner kepada masing-masing responden yang terlibat dalam proses penyelenggaraan Ujian Akhir Semester Non Pendas 2017.1 pada Unit Program Belajar Jarak Jauh Universitas Terbuka Makassar (UPBJJ-UT) sebagai berikut:

\section{Penanggung Jawab Tempat Ujian (PJTU)}

Berdasarkan kuesioner yang telah di analisis dari 4 orang responden dengan item pertanyaan yang diajukan sebanyak 15 pertanyaan diperoleh hasil analisis sebagai berikut:

Bahwa hasil dari evaluasi penyelenggaraan ujian akhir semester Non Pendas 2017.1 yang dilaksanakan oleh Penanggung Jawab Tempat Ujian (PJTU) dengan indikator evaluasi dari kouesioner yang dibagikan kepada responden dinyatakan telah efektif dan efisien yakni dari 4 orang PJTU semua memberikan jawaban Ya yakni sebanyak 100\% dengan kriteria penilaian: 1) mengikuti pengarahan (penyamaan presepsi) dari koordinator Regjian tentang pelaksanaan ujian, 2) menerima daftar peserta ujian dan tata tertib peserta ujian dari koordinator Regjin, 3) mengisi rekapitulasi kebutuhan naskah ujian berdasarkan daftar peserta ujian, 4) mengecek kesesuaian jumlah bahan pendukung ujian, 5) mengidentifikasi kesesuaian jumlah dan kepastian ruang ujian dan dengan daftar peserta ujian, 6) menerima amplop naskah ujian dari koordinator regjian (UJ02-RK17b-RII.0), 7) mengidentifikasi kesesuaian kode dan jumlah naskah ujian,

menyerahkan naskah ujian untuk setiap ruang ujian ke PJLU dengan mengisi UJ02RK03-RII.0, 9) menerima amplop naskah dan hasil ujian serta sisa bahan dan naskah ujian, serta memeriksa kelengkapan isi amplop hasil ujian, 10) menerima kelengkapan arsip daftar hadir dan berita acara pelaksanaan ujian per ruang ujian, 11) memeriksa kebenaran pengisian daftar rekapitulasi jumlah LJU/BJU hasil ujian untuk tiap ruang/jam ujian, 12) memasukkan semua amplop hasil ujian ke dalam box, diikat, ditutup dan lakban, 13) mengumpulkan semua LJU/BJU yang tidak terpakai untuk diserahkan kembali ke koordinator regjian, 14) mengumpulkan semua sisa naskah ujian kemudian dimusnahkan dengan cara dibakar dengan menggunakan form UJ02-RK06-RII.0, dan 15) menyerahkan box hasil ujian beserta sisa bahan pendukung kepada koordinator regjian.

\section{Penanggung Jawab Lokasi Ujian (PJLU)}

Berdasarkan hasil kuesioner yang telah di analisis dari 4 orang responden dengan item pertanyaan yang diajukan sebanyak 16 pertanyaan diperoleh hasil analisis yang dapat disajikan hasil sebagai berikut:

Bahwa hasil dari evaluasi penyelenggaraan ujian akhir semester Non Pendas 2017.1 yang dilaksanakan oleh Penanggung Jawab Lokasi Ujian (PJLU) dengan indikator evaluasi dari kouesioner yang dibagikan kepada responden dinyatakan telah efektif dan efisien yakni semua responden memberikan jawaban Ya yakni sebanyak $100 \%$ dengan kriteria penilaian: 1) mengikuti pengarahan (penyamaan presepsi) dari PJTU tentang teknis pelaksanaan ujian, 2) menerima daftar peserta ujian dan tata tertib peserta ujian dari PJTU, 3) mempersiapkan lokasi ujian sesuai kebutuhan ruang per hari ujian, 4) menerima naskah ujian dan bahan pendukung untuk setiap ruang ujian dari PJTU, 5) membagikan tanda pengenal kepada panitia ujian dan mengumpulkan kembali setelah selesai ujian, 6) memberikan penjelasan tentang pelaksanaan ujian dan tanggungjawab pengawas ruang ujian, 7) membagikan bahan ujian kepada pengawas ruang pada jam 1 dan 4 , serta membagikan kepada pengawas keliling untuk jam ke 2,3, 
dan 5,8) mengkoordinir tanda/bel/lonceng untuk memulai dan ujian selesai, 9) menerima hasil dan naskah ujian dari pengawas ruang ( jam $3 \& 5$ ), dari pengawas keliling ( jam 1,2,dan 4), 10) mengkoordinasi pemeriksaan kesesuaian jumlah hasil ujian dan naskah ujian yang diterima per jam ujian, 11) memeriksa kelengkapan isi amplop hasil ujian dan menandatangani setiap amplop hasil ujian dari setiap ruang ujian, 12) memeriksa kelengkapan arsip daftar hadir dan berita acara pelaksanaan ujian per ruang ujian yang akan diserahkan ke PJTU, 13) memeriksa kebenaran pengisian daftar rekapitulasi jumlah LJU/BJU hasil ujian untuk tiap ruang/jam ujian dan menandatanganinya, 14) mengkoordinasikan pengepakan hasil ujian per hari ujian, 15) menyerahkan kepada PJTU box hasil ujian beserta amplop yang berisi arsip daftar hadir dan berita acara pelaksanaan ujian, dan 16) memusnahkan naskah ujian per hari di lokasi ujian.

\section{Pengawas Keliling (PK)}

Berdasarkan hasil kuesioner yang telah di analisis dari 8 orang responden dengan item pertanyaan yang diajukan sebanyak 11 pertanyaan diperoleh hasil analisis yang dapat disajikan hasil sebagai berikut:

Bahwa hasil dari evaluasi penyelenggaraan ujian akhir semester Non Pendas 2017.1 yang dilaksanakan oleh Pengawas Keliling (PK) dengan indikator evaluasi dari kouesioner yang dibagikan kepada responden dinyatakan telah efektif dan efisien yakni dari 8 orang Pengawas Keliling yang memberikan jawaban Ya sebanyak 7 orang atau $88 \%$, sedangkan yang menyatakan "Tidak" sebanyak 1 orang atau $12 \%$ dengan kriteria penilaian: 1) mengikuti pengarahan (penyamaan presepsi) dari PJTU tentang teknis pelaksanaan ujian, 2) meminta bahan ujian untuk jam ujian ke 2,3, dan 5 kepada PJLU, 3) mengantar bahan ujian ke ruang ujian dan menyerahkannya kepada pengawas ruang 15 menit sebelum ujian dan mengisi UJ02-RK01-RII.0, 4) mengecek tanda tangan pengawas ujian pada LJU dan daftar hadir, 5) menerima daftar kekurangan naskah ujian (bila ada) dari pengawas ruang, untuk disampaikan ke PJLU, 6) mengingatkan pengawas ruang untuk memeriksa kebenaran pengisian LJU/BJU, daftar hadir, dan UJ02-RK02RII.0, 7) mengecek tanda tangan pengawas ruang pada LJU/BJU dan daftar hadir, 8) mengganti fungsi pengawas ruang untuk sementara apabila pengawas ruang memerlukan keluar ruang ujian, 9) melaporkan peda PJLU bila terjadi kesulitan/masalah dalam pelaksanaan ujian di ruang ujian yang tidak dapat diatasi, 10) mengambil LJU/BJU, naskah ujian dan sisa LJU/BJU dari setiap ruang ujian dan mencocokkan jumlah LJU/BJU yang diterima dengan daftar hadir dan UJ02RK02, 11) menyerahkan hasil ujian setelah jam ujian ke 1, 2, dan 4 ke PJLU/sekretaris ujian dan menandatangani UJ02-RK01RII.0.

\section{Pengawas Ruang Ujian (PRU)}

Berdasarkan kuesioner yang telah di analisis dari 53 orang responden dengan item pertanyaan yang diajukan sebanyak 23 pertanyaan diperoleh hasil analisis yang dapat disajikan hasil sebagai berikut:

Bahwa hasil dari evaluasi penyelenggaraan ujian akhir semester Non Pendas 2017.1 yang dilaksanakan oleh Pengawas Ruang Ujian dengan indikator evaluasi dari kouesioner yang dibagikan kepada responden dinyatakan telah efektif dan efisien yakni dari 53 orang Pengawas Ruangan yang memberikan jawaban Ya sebanyak 48 orang atau $92 \%$ dan yang menyatakan Tidak sebanyak 5 orang atau 8\% dengan kriteria penilaian: 1) mengikuti pengarahan (penyamaan presepsi) dari PJTU tentang teknis pelaksanaan ujian, 2) mengambil bahan ujian untuk jam ujian ke 1, dan 4 di secretariat, dan pada jam ujian selanjutnya akan diantar pengawas keliling, 3) memeriksa kelengkapan bahan ujian dan menandatangani berita acara serah terima dari PJTU ke pengawas keliling/pengawas ruang demikian pula untuk penyerahan hasil ujian, 4) mempersilahkan peserta ujian memasuki ruang ujian dan duduk di tempat yang telah ditentukan 10 menit sebelum 
ujian dimulai, 5) memintah peserta ujian meletakkan semua barang bawaaan di bagian depan ruang ujian, kecuali kartu mahasiswa, KTPU, dan alat tulis (modul dan kalkulator hanya digunakan untuk mata kuliah tertentu), 6) meminta peserta ujian meletakkan kartu mahasiswa, KTPU, dan identitas lain untuk memudahkan pemeriksaan indentitas,7) membacakan tata tertib ujian pada jam pertama ujian, dan mengingatkan mahasiswa tentang tata tertib tersebut, 8) membuka kemasan naskah ujian yang disaksikan oleh dua orang peserta ujian dan menandatangani BA pelaksanaan ujian, 9) menghitung dan mencocokkan jumlah naskah ujian sesuai daftar peserta, 10) membagikan naskah ujian dan LJU/BJU kepada peserta ujian sesuai KTPU dan daftar peserta ujian, 11) memberikan tanda bahwa ujian dapat dimulai, 12) meminta peserta ujian memeriksa kelengkapan halaman naskah ujian, bila terdapat kekurangan, maka dapat menghubungi pengawas keliling dan mengisi daftar kekurangan naskah ujian, 13) mengedarkan daftar hadir sekaligus memeriksa kebenaran identitas peserta ujian dan memeriksa tanda tangan pada LJU/BJU, 14) menegur peserta ujian yang melakukan kecurangan dan mencatat NIM, nama, mata kuliah pada UJ02-RK06-RII.0, 15) mencoret daftar hadir nama peserta yang tidak hadir setelah 30 menit ujian berlangsung, 16) menandatangani UJ02-RK02-RII0 dan daftar hadir pada setiap jam ujian, 17) memberi tanda silang LJU digital yang tidak dipakai dan memasukkan dalam amplop hasil ujian (tidak dhitung hasil ujian), 18) mengumpulkan LJU/BJU dan naskah ujian (kecuali TAP), 19) memeriksa kembali kebenaran identitas LJU/BJU peserta ujian dan menandatangani LJU/BJU yang sudah diperiksa, 20) memisahkan LJU dan BJU lalu mengurutkan sesuai daftar hadir, 21) melipat masing-masing 1 lembar UJ02RK02-RII.0 terisi pada LJU dan BJU yang sudah diurutkan, 22) menyerahkan naskah ujian ke pengawas keliling pada jam ujian ke 1, 2, dan 4 atau ke PJLU pada jam ujian ke 3 , dan 5 dan menandatangani UJ02-RK01RII.0 setiap jam ujian, 23) menyerahkan naskah ujian ke PJLU pada jam ujian ke 3, dan 5 dan menandatangani UJ02-RK01RII.0 setiap jam ujian.

\section{Mahasiswa}

Berdasarkan kuesioner yang telah di analisis dari 115 orang mahasiswa dengan item pertanyaan yang diajukan sebanyak 16 pertanyaan diperoleh hasil analisis yang dapat disajikan hasil sebagai berikut:

Bahwa hasil dari evaluasi penyelenggaraan ujian akhir semester Non Pendas 2017.1 yang dilaksanakan oleh Pengawas Ruang Ujian dengan indikator evaluasi dari kouesioner yang dibagikan kepada responden dinyatakan telah efektif dan efisien yakni dari 115 orang yang memberikan jawaban Ya sebanyak 100 orang atau 87\%, sedangkan yang menyatakan Tidak sebanyak 15 orang atau $13 \%$, dengan kriteria penilaian: 1) ketersediaan informasi pelaksanaan ujian (jadwal, tata tertib, 2) masuk ruang ujian dan duduk di tempat yang telah ditentukan (sesuai dengan nomor meja dengan kartu ujian) 10 menit sebelum ujian dimulai, 3) meletakkan semua barang bawaan di bagian depan ruang ujian, kecuali kartu mahasiswa, KTPU, dan alat tulis (modul dan kalkulator hanya digunakan untuk mata kuliah tertentu), 4) meletakkan kartu mahasiswa, KTPU, dan identitas lain untuk memudahkan pemeriksaan identitas, 5) dibacakan tata tertib ujian dan anti menyontek dan anti plagiat oleh pengawas ruang sebelum ujian, 6) melihat pengawas ujian membuka kemasan naskah ujian yang disaksikan oleh dua orang peserta ujian dan menandatangani berita acara pelaksanaan ujian, 7) dibagikan naskah ujian dan LJU/BJU sesuai KTPU dan daftar peserta ujian, 8) mendengar/diberikan informasi tanda bahwa ujian dapat dimulai, 9) sarana penyelengggaraan ujian memadai seperti ruang ujian terang, tersedia kamar kecil, dan ruang shalat, 10) soal-soal ujian bersumber dari BMP/Modul, 11) pengawas ruang dan pengawas keliling sudah bertugas tepat waktu dan dengan baik, 12) mengerjakan soal-soal ujian tidak ada kesulitan dalam memahami soal, 13) PJTU/PJLU/Pemantau 
melakukan survey di ruangan pada saat ujian berlangsung, 14) ditegur oleh pengawas ruang yang melakukan kecurangan dan mencatat NIM, nama, mata kuliah, pada UJ02-RK02-RII.0, 15) meja dalam ruang ujian terasa layak untuk menulis dan merasa tenang pada saat ujian berlangsung, 16) mengerjakan soal ujian tetap waktu.

\section{Tenaga Administrasi (TA)}

Berdasarkan kuesioner yang telah di analisis dari 7 orang tenaga administrasi dengan item pertanyaan yang diajukan sebanyak 11 pertanyaan diperoleh hasil analisis yang dapat disajikan hasil sebagai berikut:

Bahwa hasil dari evaluasi penyelenggaraan ujian akhir semester Non Pendas 2017.1 yang dilaksanakan oleh Pengawas Ruang Ujian dengan indikator evaluasi dari kouesioner yang dibagikan kepada responden dinyatakan kurang efektif dan efisien yakni dari 5 orang Tenaga Administrasi yang memberikan jawaban Ya sebanyak 5 orang atau $71 \%$, sedangkan yang memberikan jawaban Tidak sebanyak 2 orang atau $29 \%$ dengan kriteria penilaian: 1) mengikuti pengarahan (penyamaan presepsi) dari PJTU tentang teknis pelaksanaan ujian, 2) mempersiapkan bahan ujian setiap jam ujian di sekretariat, 3) memeriksa kelengkapan bahan ujian dari pengawas keliling/pengawas ruang, 4) mengumpulkan LJU/BJU dan naskah ujian, 5) memeriksa kembali kebenaran identitas LJU/BJU peserta ujian, 6) memisahkan LJU dan BJU lalu mengurutkan sesuai dengan daftar hadir, 7) melipat masing-masing 1 lembar UJ02-RK02-RII.0 terisi pada LJU dan BJU yang sduah diurutkan, 8) menyerahkan naskah ujian dan LJU/BJU ke pengawas ruang pada jam ujian ke 1 , dan 4 , 9) menerima naskah ujian dan LJU/BJU dari pengawas ruang setelah selesai pada jam ke 3 , dan 5, 10) menyerahkan naskah ujian dan LJU/BJU ke pengawas keliling pada jam ujian ke 2, 3 dan 5, dan 11) menerima naskah ujian dan LJU/BJU dari pengawas keliling setelah selesai jam ke 1, 2, dan 4 .

\section{Rekapitulasi Hasil Evaluasi Penyelenggaraan Ujian Akhir Semester Mahasiswa Program Non Pendas}

Ujian akhir semester bertujuan untuk menguji kemampuan mahasiswa dalam menguasai materi suatu mata kuliah. Soalsoal UAS dikembangkan di UT Pusat dalam bentuk tes objektif dan tes uraian. Pada saat pelaksanaan UAS mahasiswa menjawab soal ujian pada Lembar Jawaban Ujian (LJU) untuk mengerjakan tes objektif, dan pada Buku Jawaban Ujian (BJU) untuk mengerjakan tes uraian. Seluruh penyelenggaraan UAS di daerah yang sudah ditunjuk sebagai tempat ujian oleh UT Pusat diatur oleh UPBJJ setempat. Hasil UAS yang berbentuk tes objektif dinilai secara terpusat di UT Pusat dengan menggunakan komputer, sedangkan hasil UAS uraian dinilai oleh dosen yang berada pada rayon UPBJJ sentra yang telah ditentukan oleh UT Pusat. UPBJJ-UT Makassar merupakan salah satu UPBJJ sentra untuk wilayah Indonesia Timur yang meliputi 10 UPBJJ yaitu: Makassar, Majene, Manado, Gorontalo, Palu, Kendari, Ternate, Ambon, Jayapura, dan Sorong.

Untuk mengetahui sejauh mana keberhasilan pelaksanaan UAS program Non Pendas di UPBJJ-UT Makassar untuk masa ujian 2017.1 perlu dilakukan evaluasi terhadap persiapan dan pelaksanaannya.

Berdasarkan hasil analisis data dari masing-masing jawaban responden berdasarkan kuesioner yang dibagikan kepada PJTU, PJLU, Pengawas Keliling, Pengawas Ruang, Mahasiswa dan Tenaga Administrasi diperoleh hasil analisis yang dapat disajikan hasil sebagai berikut:

Bahwa dari jumlah reseponden sebanyak 191 orang dengan item pertanyaan sebanyak 92 yang masing-masing orang yang terlibat dalam proses penyelengggaran ujian akhir semester mahasiswa program non pendas pada masa ujian 2017.1 yang terdiri dari PJTU sebanyak 4 orang dengan item pertanyaan sebanyak 15 yang kesemuanya memberikan jawaban "Ya" atau $100 \%$. Sedangan PJLU sebanyak 4 orang dengan item pertanyaan 16 juga semua 
memberikan alternatife jawaban Ya atau $100 \%$. Pengawas Keliling dengan jumlah responden sebanyak 8 orang dan 11 item pertanyaan, 7 orang atau $88 \%$ memberikan alternative jawaban Ya, dan 1 orang atau 12 $\%$ menyatakan tidak. Pengawas Ruang dengan jumlah responden sebanyak 53 orang dan 23 item pertanyaan, 48 orang atau 91\% memberikan alternative jawaban Ya, dan 5 orang atau 9\% menyatakan tidak. Mahasiswa dengan jumlah sebanyak 115 orang dan 16 item pertanyaan, 100 orang atau $87 \%$ memberikan jawaban Ya dan 15 orang atau $13 \%$ menyatakan tidak. Sedangkan Tenaga Administrasi dengan jumlah 7 orang dan 11 item pertanyaan, 5 orang tenaga administrasi atau $71 \%$ memberikan jawaban Ya, dan 2 orang atau $29 \%$ menyatakan tidak.

Rekapitulasi Hasil analisis dapat disimpulkan bahwa evaluasi penyelenggaraan ujian akhir semester Non Pendas 2017.1 yang dilaksanakan oleh penyelenggara ujian yang terdiri dari PJTU, PJLU, Pengawas Keliling, Pengawas Ruang, Mahasiswa dan Tenaga Administrasi dinyatakan sangat efektif dan efisien. dengan ketercapaian $88 \%$ yang menyatakan bahwa penyelenggaraan ujian akhir semester berjalan dengan sangat efektif dan efisien sesuai dengan aturan penyelenggaran ujian yang ditetap oleh pelaksana UAS program Non Pendas di UPBJJ-UT Makassar untuk masa ujian 2017.1. sedangkan $12 \%$ yang menyatakan tidak disebabkan bahwa tenaga administrasi yang ada belum mampu menyelenggarakan UAS dengan baik karena keterbatasan yang tersedia serta kemampuan teknis yang dimilik masing-masing staf.

\section{KESIMPULAN}

\section{Kesimpulan}

Berdasarkan hasil penelitian dari analisis data penelitian maka dapat ditarik beberapa simpulan yang dapat dikemukakan sebagai berikut :

1. Penanggung Jawab Tempat Ujian (PJTU) telah memahami tugas dan fungsinya masing-masing sehingga dalam proses penyelenggaran UAS program Non Pendas di UPBJJ-UT
Makassar untuk masa ujian 2017.1. hal ini ditunjukkan bahwa $100 \%$ menyatakan bahwa penyelenggaran UAS sudah berjalan sesuai dengan prosedur dan petunjuk teknis yang ada.

2. Penanggung Jawab Lokasi Ujian (PJTU) sangat memahami tugas dan fungsinya masing-masing sehingga dalam proses penyelenggaran UAS program Non Pendas di UPBJJ-UT Makassar untuk masa ujian 2017.1. hal ini ditunjukkan bahwa $100 \%$ menyatakan bahwa penyelenggaran UAS sudah berjalan sesuai dengan prosedur dan petunjuk teknis yang ada.

3. Pengawas Keliling (PK) telah melaksanakan tugas dan fungsinya masing-masing sehingga dalam proses penyelenggaran UAS program Non Pendas di UPBJJ-UT Makassar untuk masa ujian 2017.1. hal ini ditunjukkan bahwa $88 \%$ menyatakan bahwa penyelenggaran UAS sudah berjalan sesuai dengan prosedur dan petunjuk teknis yang ada.

4. Pengawas Ruang (PRU) telah memahami tugas dan fungsinya masingmasing sehingga dalam proses penyelenggaran UAS program Non Pendas di UPBJJ-UT Makassar untuk masa ujian 2017.1. hal ini ditunjukkan bahwa $91 \%$ menyatakan bahwa penyelenggaran UAS sudah berjalan sesuai dengan prosedur dan petunjuk teknis yang ada.

5. Mahasiswa dalam proses pelaksanaan UAS telah proses penyelenggaran UAS program Non Pendas di UPBJJ-UT Makassar untuk masa ujian 2017.1. dengan sangat efektif dan efisien. Hal ini ditunjukkan bahwa $87 \%$ menyatakan bahwa penyelenggaran UAS sudah berjalan sesuai dengan prosedur dan petunjuk teknis yang ada

6. Tenaga Administrasi belum melaksanakan tugas dan fungsinya masing-masing dengan baik dalam proses penyelenggaran UAS program Non Pendas di UPBJJ-UT Makassar untuk masa ujian 2017.1. hal ini 
ditunjukkan bahwa $71 \%$ menyatakan bahwa penyelenggaran UAS belum berjalan sesuai dengan prosedur dan petunjuk teknis yang ada.

Secara keseluruhan unsur yang terlibat dalam proses penyelenggaran UAS program Non Pendas di UPBJJ-UT Makassar untuk masa ujian 2017.1.diantaranya PJTU, PJLU, Pengawas Keliling, Pengawas Ruang, Mahasiswa dan Tenaga Administrasi semua telah mendukung dengan baik terselenggaranya UAS program Non Pendas di UPBJJ-UT Makassar untuk masa ujian 2017.1. hal ini ditunjukkan bahwa $88 \%$ yang menyatakan UAS dapat berjalan sesuai dengan aturan yang berlaku dan berjalan dengan lancer sesuai prosedur yang ada di UPBJJ-UT Makassar.

Saran

Sehubungan dengan hasil penelitian yang telah dikemukakan sebelumnya serta implikasinya dalam memenuhi penyelenggaran UAS program Non Pendas di UPBJJ-UT Makassar, maka berikut ini dikemukakan saran :

1. Untuk mencapai terselenggarannya UAS program Non Pendas di UPBJJ-UT Makassar, maka diharapkan:

a. Perlunya dilakukan evaluasi penyelenggaran UAS program Non Pendas di UPBJJ-UT Makassar setiap semester.

b. Perlunya ada tindak lanjut atas hasil evaluasi yang telah dilaksanakan sebelum agar dapat memperbaik kekurangan/kesalahan yang terjadi dalam proses penyelenggaran.

2. Tenaga administrasi perlu dilibatkan secara penuh dalam proses penyelenggaran UAS program Non Pendas di UPBJJ-UT Makassar, serta peningkatan kapasitas dan kompetensi mereka sebagai tenaga kependidikan yang mendukung penyelenggaraan pendidikan yang bermutu.
DAFTAR RUJUKAN

Gay, L. R. 1987. Educational Research. New York: Merill and Macmillan Pub. And Co.

Sugiyono.2001. Metode Penelitian Bisnis. Bandung: Alfabeta.

Suparman, 2009. Evaluasi Terhadap Kegiatan Pelaksanaan UAS Program D II Guru SD di Eks Karasidenan Semarang. Jurnal Pendidikan Universitas Terbuka, 6 (1). Maret 2005.

Zaidin A., 2010. Upaya Peningkatan Kualitas Pelaksanaan Ujian Akhir Semester Program Pendidikan Dasar di Unit Program Belajar Jarak Jauh Universitas Terbuka Makassar. Laporan hasil penelitian LPPMUT. 